Jurnal Agro 8(2), 2021

\title{
FORMULA PADAT Bacillus cereus STRAIN TLE1.1 UNTUK PENGENDALIAN PENYAKIT BUSUK PANGKAL BATANG (Sclerotium rolfsii) PADA TANAMAN TOMAT
}

\section{SOLID FORMULA OF Bacillus cereus STRAIN TLE1.1 FOR THE CONTROL OF STEM ROT DISEASE (Sclerotium rolfsii) IN TOMATO PLANTS}

\author{
Yulmira Yanti*, Hasmiandy Hamid, Reflin, Yaherwandi Febri Yani Chrismont \\ Program Studi Proteksi Tanaman, Fakultas Pertanian, Universitas Andalas, \\ Limau Manis, Kec. Pauh, Kota Padang, Sumatera Barat 25163 \\ Korespondensi: yy.anthie79@gmail.com
}

Diterima : 25 November 2021 / Disetujui : 16 Desember 2021

\begin{abstract}
ABSTRAK
Penyakit utama tanaman tomat yaitu busuk pangkal batang yang disebabkan oleh Sclerotium rolfsii dapat menimbulkan kerugian mencapai $80-100 \%$. Tujuan penelitian yaitu untuk mendapatkan formula padat Bacillus cereus strain TLE1.1 yang efektif untuk pengendalian penyakit busuk pangkal batang pada tanaman tomat. Penelitian bersifat eksperimen dengan mengamati kemampuan formula padat $B$. cereus strain TLE1.1 dalam pengendalian penyakit busuk pangkal batang dengan Rancangan Acak Lengkap yang terdiri atas 9 perlakuan dan 3 ulangan. Perlakuan terdiri atas kombinasi bahan pembawa formula padat yang terdiri atas limbah padat ampas tebu, ampas tahu dan tongkol jagung, fungisida serta kontrol. Masing-masing formula padat $B$. cereus strain TLE1.1 diintroduksi pada benih dan bibit tomat. Hasil penelitian menunjukkan bahwa hampir semua formula mampu menekan penyakit busuk pangkal batang tanaman tomat. Formula terbaik dalam menurunkan penyakit busuk pangkal batang pada tanaman yaitu formula ampas tahu dan ampas tahu + tongkol jagung.
\end{abstract}

Kata kunci: Busuk pangkal batang, Formula padat, Sclerotium rolfsii, Tomat

\begin{abstract}
Main disease of tomato plant, namely stem rot caused by Sclerotium rolfsii which can cause losses up to $80-100 \%$. The aim of the study was to obtain a solid formula of Bacillus cereus strain TLE1.1 which was effective for controlling stem rot disease in tomato plant. This research was an experimental study to know the ability of the solid formula of $B$. cereus strain TLE1.1 in controlling stem rot disease which was carried out in a completely randomized design consisting of 9 treatments and 3 replications. The treatment consisted of a combination of solid formula carriers consisting of sugarcane solid waste, tofu dreg and corncob, fungicides and controls. Each solid formula of $B$. cereus strain TLE1.1 was introduced into tomato seeds and seedlings. The results showed that almost all of the formulas were able to suppress stem base disease of tomato plants. The best formula that reduced stem rot in plants were the tofu dreg and tofu dreg + corncob formula.
\end{abstract}

Keywords: Sclerotium rolfsii, Solid formula, Stem rot, Tomato

ISSN : 2407-7933

Cite this as: Yanti, Y., Hamid, H., Reflin., Yaherwandi., \& Christmont, F, Y. (2021). Formula padat Bacillus cereus STRAIN TLE1.1 untuk pengendalian penyakit busuk pangkal batang (Sclerotium rolfsii) pada tanaman tomat. Jurnal Agro, 8(2), 226-236. https://doi.org/10.15575/14679 


\section{PENDAHULUAN}

Tomat adalah salah satu komoditas sayuran yang multiguna, selain sebagai sayuran juga digunakan sebagai bahan baku industri obat - obatan dan kosmetik serta bahan baku pengolahan makanan (Wijayanti \& Susila, 2013). Faktor penyebab rendahnya produktivitas tomat adalah serangan hama dan penyakit tanaman, salah satunya yaitu busuk pangkal batang oleh Sclerotium rolfsii (Sekhar et al., 2020). S. rolfsii merupakan patogen tular tanah yang memiliki kisaran inang yang luas dan dapat bertahan lama pada berbagai jenis sisa tanaman di dalam tanah (Rivard et al., 2012). Gejala penyakit ini yaitu terjadi luka pada bagian pangkal batang tanaman sehingga tanaman menjadi layu secara tiba-tiba dan permanen. Terdapat miselium yang lama kelamaan akan membentuk sklerotia pada bagian pangkal batang. Sklerotia tersebut mampu bertahan lama di dalam tanah sebagai struktur bertahan S. rolfsii (Dixit $n$ et al., 2016).

Pengendalian busuk pangkal batang yang telah dilakukan yaitu secara kultur teknis, rotasi tanaman, pengaturan pola tanam, pengaturan drainase yang baik, penggunaan benih sehat, penggunaan varietas tahan (Kator et al., 2015) serta aplikasi fungisida, yang dapat memberikan dampak negatif terhadap lingkungan (Saeed et al., 2016). Sehingga diperlukan suatu alternatif pengendalian yaitu dengan memanfaatkan mikroorganisme sebagai agens pengendali hayati (Natalia et al., 2014).

Salah satu agens hayati yang telah teruji dapat mengendalikan penyakit tanaman serta banyak digunakan yaitu bakteri endofit (Sahu et al., 2019). Bakteri endofit merupakan bakteri yang hidup di dalam jaringan tanaman dan tidak menimbulkan penyakit atau perubahan morfologi yang signifikan pada tanaman (Wang et al., 2019). Kelompok bakteri endofit yang berperan sebagai agens pengendali penyakit secara hayati diantaranya Pseudomonas, Burkholderia, Azospirillum dan Bacillus (Taghavi et al., 2005).

Kelompok dari Bacillus spp. yang berperan sebagai agens biokontrol yaitu Bacillus thuringiensis, Bacillus mycoides, Bacillus pseudomycoides, Bacillus bingmayongensis dan Bacillus cereus (Flori et al., 2020). Selanjutnya Joo et al. (2004) menyatakan bahwa $B$. cereus mampu meningkatkan pertumbuhan tanaman dengan menghasilkan hormon pertumbuhan seperti giberelin. Keberhasilan penggunaan Bacillus spp. yaitu bisa menghambat pertumbuhan jamur Fusarium oxysporum (Diarta et al., 2016). Penggunaan Bacillus sp. secara tunggal menyebabkan Bacillus sp. tidak dapat bertahan lama dan kurang optimal baik sebagai agens biokontrol maupun sebagai bioaktivator, hal ini disebabkan karena bakteri membutuhkan nutrisi sehingga perlu dibuat formulasi bakteri (Oktrisna et al., 2017; Yanti et al., 2017).

Penelitian bertujuan untuk mendapatkan formula padat $B$. cereus strain TLE1.1 yang efektif untuk mengendalikan penyakit busuk pangkal batang pada tanaman tomat.

\section{BAHAN DAN METODE}

Penelitian dilaksanakan pada Maret Agustus 2021 di laboratorium Mikrobiologi dan kebun percobaan Fakultas Pertanian, Universitas Andalas, Padang. Penelitian 
bersifat eksperimen menggunakan Rancangan Acak Lengkap (RAL) dengan 9 perlakuan dan 3 ulangan. Perlakuan terdiri atas, formula B. cereus strain TLE1.1 dengan berbagai bahan pembawa dari limbah organik yaitu: ampas tebu (AT), ampas tahu (AH), tongkol jagung (TJ) dan kombinasi limbah organik AT + AH, AT + TJ dan $\mathrm{AH}+\mathrm{TJ}$ dengan perbandingan 1:1 $(\mathrm{v} / \mathrm{v})$, perlakuan fungisida berbahan aktif Mancozeb, perlakuan tanpa diformulasi dan tanpa diinokulasi S. rolfsii (kontrol positif), perlakuan tanpa diformulasi dan diinokulasi S. rolfsii (kontrol negatif).

\section{Persiapan B. cereus strain TLE1.1}

Persiapan B. cereus strain TLE1.1 diambil dari koleksi Dr. Yulmira Yanti. Isolat B. cereus strain TLE1.1 dari mikrotube diremajakan dengan metode gores pada medium TSA, kemudian diinkubasi selama $2 \times 24$ jam.

\section{Konfirmasi B. cereus strain TLE1.1}

Konfirmasi $B$. cereus strain TLE1.1 dilakukan dengan uji Gram untuk mengetahui apakah bakteri bersifat gram negatif atau positif. Larutan $\mathrm{KOH} 3 \%$ diteteskan di atas kaca objek, kemudian ditambahkan 1 koloni tunggal biakan murni B. cereus strain TLE1.1 (Schaad et al., 2001). Kemudian dilakukan uji reaksi hipersensitif (HR) dengan cara suspensi $B$. cereus strain TLE1.1 dengan kerapatan $10^{8}$ $\mathrm{CFU} / \mathrm{ml}$ diinfiltrasikan pada jaringan permukaan bawah daun Mirabilis jalappa diinkubasi selama 2×24 jam (Klement et al., 1990).

\section{Perbanyakan B. cereus strain TLE1.1}

Perbanyakan B. cereus strain TLE1.1 dilakukan pada kultur cair dengan cara biakan murni $B$. cereus strain TLE1.1 berumur $2 \times 24$ jam diambil, dimasukkan ke $25 \mathrm{ml}$ medium NB dalam botol kultur (volume $50 \mathrm{ml}$ ) diinkubasi pada rotary shaker selama 24 jam. Selanjutnya $1 \mathrm{ml}$ hasil preculture dipindahkan ke dalam 49 $\mathrm{ml}$ air kelapa steril dalam botol kultur (volume $100 \mathrm{ml}$ ) untuk mainculture dan diinkubasi dengan cara yang sama selama 2x24 jam dengan kecepatan $150 \mathrm{rpm}$. Kerapatan populasi ditentukan dengan membandingkan kekeruhan suspensi bakteri dengan larutan McFarland skala 8 (kepadatan populasi diperkirakan $10^{8} \mathrm{sel}$ $\mathrm{ml}^{-1}$ ) (Klement et al., 1990).

\section{Persiapan bahan pembawa formula padat B. cereus strain TLE1.1}

Bagian lunak ampas tebu diambil dan digunting berukuran kecil kemudian diblender, ampas tahu dimasukkan ke aluminium foil kemudian dioven, tongkol jagung dipotong berukuran kecil kemudian diblender. Masing-masing bahan pembawa diambil sebanyak 9,5 g dimasukkan ke dalam botol Schott volume $100 \mathrm{ml}$ dan ditambahkan 0,5 g sukrosa, kemudian disterilisasikan menggunakan autoklaf tekanan $1 \mathrm{~atm}$ pada suhu $121^{\circ} \mathrm{C}$ selama 15 menit. Formula didinginkan dan ditambahkan $5 \mathrm{ml}$ suspensi $B$. cereus strain

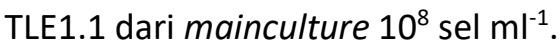

\section{Persiapan inokulum S. rolfsii}

Sumber inokulum S. rolfsii diambil dari tanaman tomat yang bergejala busuk pangkal batang dari Nagari Alahan Panjang, Kabupaten Solok kemudian dibawa ke Laboratorium. Isolasi dilakukan dengan metode tanam langsung dengan cara memotong bagian pangkal batang tomat yang terserang $0,5 \mathrm{~cm} \times 0,5 \mathrm{~cm}$ dengan mengikutkan bagian tanaman yang sehat. Selanjutnya disterilisasi permukaan dengan cara dicelupkan selama 15 detik ke 
aquadest steril, alkohol $70 \%$ dan aquadest steril. Kemudian potongan bagain tanaman diletakkan pada cawan petri yang telah berisi media PDA sebanyak 5 potong/petri. Jamur yang tumbuh dari bagian tanaman tersebut dimurnikan kembali pada media PDA dan diinkubasi selama $5 \times 24$ jam. Kemudian diamati bentuk mikroskopis dari S. rolfsii di bawah mikroskop. Hasil pengamatan mikroskopis $S$. rolfsii dibandingkan dengan buku Watanabe (2002).

\section{Uji Patogenisitas}

Uji patogenisitas dilakukan dengan cara menggunakan fungal mat dari biakan $S$. rolfsii. Fungal mat $S$. rolfsii dipotong dengan ukuran $1 \mathrm{~cm} \times 1 \mathrm{~cm}$ ditempelkan pada pangkal batang tanaman tomat yang berumur 4 minggu setelah tanam, kemudian diamati sampai muncul gejala (Kwon \& Park, 2002).

\section{Perbanyakan S. roflsii}

Perbanyakan S. rolfsii merujuk pada penelitian Oktania et al. (2018), menggunakan media Corn Meal Sand (CMS) (1000 g pasir $+200 \mathrm{~g}$ tepung jagung + aquadest steril), kemudian media tersebut dimasukkan ke kantong plastik dan diautoklaf. Selanjutnya sebanyak 5 fungal mat $S$. rolfsii dimasukkan ke media tersebut dan diinkubasi selama 20 hari pada suhu ruang.

\section{Persiapan media tanam}

Komposisi media tanam yang digunakan yaitu campuran tanah dan pupuk kandang 2:1 (v/v). Media tanam dimasukkan ke dandang untuk disterilisasi selama 1 jam pada suhu $100{ }^{\circ} \mathrm{C}$. Kemudian tanah yang sudah steril didinginkan selama 24 jam. Media tanam tersebut dimasukkan ke seedtray sebanyak $20 \mathrm{~g} \mathrm{lubang}^{-1}$ untuk persemaian dan $10 \mathrm{~kg}$ ke polybag untuk penanaman (Yanti et al., 2017).

\section{Introduksi formula $B$. cereus strain TLE1.1}

Introduksi formula $B$. cereus strain TLE1.1 dilakukan sebanyak 2 kali. Introduksi dilakukan pada saat penyemaian dan penanaman.

\section{Inokulasi S. rolfsii}

S. rolfsii yang ditumbuhkan pada media Corn Meal Sand (CMS) selama 20 hari diinokulasikan ke tanaman tomat berumur 4 minggu setelah tanam. Inokulasi dilakukan dengan cara membuat lobang pada kedalaman $2 \mathrm{~cm}$ dengan jarak $5 \mathrm{~cm}$ dari pangkal batang tomat kemudian media CMS yang mengandung $S$. rolfsii ditaburkan sebanyak $50 \mathrm{~g}$ dan ditutup dengan selapis tanah.

\section{Pengamatan}

Pengamatan dilakukan terhadap perkembangan penyakit, pertumbuhan bibit tomat dan pertumbuhan tanaman. Pengamatan perkembangan penyakit meliputi masa inkubasi, kejadian penyakit dan keparahan penyakit. Pengamatan pertumbuhan bibit meliputi daya muncul lapang, tinggi bibit (cm), jumlah daun bibit, berat basah bibit dan berat kering bibit. Pengamatan pertumbuhan tanaman tomat meliputi tinggi tanaman $(\mathrm{cm})$, jumlah daun dan muncul bunga pertama. Data dianalisis dengan sidik ragam, jika berbeda nyata maka dilanjut dengan Duncan's New Multiple Range Test (DNMRT) pada taraf $5 \%$.

\section{HASIL DAN PEMBAHASAN}

Tanaman tomat yang diintroduksi formula padat $B$. cereus strain TLE1.1 menunjukkan pengaruh pada masa inkubasi yang berbeda nyata (Tabel 1). 
Semua perlakuan menunjukkan berbeda tidak nyata dengan mancozeb, namun berbeda nyata dengan kontrol negatif. Namun enam belas perlakuan tersebut berbeda nyata dengan kontrol negatif. Formula terbaik memperlambat masa inkubasi penyakit busuk pangkal batang pada tomat yaitu formula ampas tahu dan ampas tahu + tongkol jagung yang ditandai dengan tidak adanya gejala pada tanaman tomat hingga akhir pengamatan (Tabel 1).

Tabel 1 Masa inkubasi penyakit busuk pangkal batang pada tanaman tomat yang diintroduksi formula padat $B$. cereus strain TLE1.1.

\begin{tabular}{ll}
\hline Perlakuan & Masa inkubasi (hsi)* \\
\hline Kontrol negatif (diinokulasi S. rolfsii) & 16,33 a \\
Mancozeb & $30,66 \mathrm{bc}$ \\
Tongkol jagung & $29,33 \mathrm{~b}$ \\
Ampas tebu + ampas tahu & $37,66 \mathrm{bc}$ \\
Ampas tebu & $38,00 \mathrm{bc}$ \\
Ampas tebu + tongkol jagung & $39,00 \mathrm{bc}$ \\
Ampas tahu & $0,00 \mathrm{c}^{* *}$ \\
Ampas tahu + tongkol jagung & $0,00 \mathrm{c} * *$ \\
\hline
\end{tabular}

*Angka-angka yang diikuti oleh huruf kecil yang tidak sama pada lajur yang sama adalah berbeda nyata berdasarkan DNMRT pada $\alpha=5 \%$.

** tanaman tidak menimbulkan gejala sampai akhir pengamatan.

Tanaman tomat yang diintroduksi formula padat $B$. cereus strain TLE1.1 menunjukkan pengaruh terhadap kejadian penyakit yang berbeda nyata (Tabel 2). Perlakuan formula ampas tahu, ampas tahu + tongkol jagung, ampas tebu, ampas tebu + tongkol jagung, ampas tebu + ampas tahu menunjukkan hasil berbeda tidak nyata dengan mancozeb, namun berbeda nyata dengan kontrol negatif. Formula terbaik memperlambat kejadian penyakit busuk pangkal batang pada tomat yaitu formula ampas tahu dan ampas tahu + tongkol jagung yang ditandai kejadian penyakit $(0,00)$ dan efektifitas $(100 \%)$ (Tabel 2).

Tabel 2. Kejadian penyakit busuk pangkal batang pada tanaman tomat yang diintroduksi formula padat B. cereus TLE1.1

\begin{tabular}{lcc}
\hline Perlakuan & Kejadian Penyakit* & Efektivitas (\%) \\
\hline Ampas tahu & $0,00 \mathrm{a}$ & 100,00 \\
Ampas tahu + tongkol jagung & $0,00 \mathrm{a}$ & 100,00 \\
Ampas tebu & $33,33 \mathrm{ab}$ & 66,67 \\
Ampas tebu + ampas tahu & $33,33 \mathrm{ab}$ & 66,67 \\
Ampas tebu + tongkol jagung & $33,33 \mathrm{ab}$ & 66,67 \\
Mancozeb & $66,66 \mathrm{ab}$ & 33,34 \\
Tongkol jagung & $100,00 \mathrm{c}$ & 0,00 \\
Kontrol negatif (diinokulasi S. rolfsii) & $100,00 \mathrm{c}$ & 0,00 \\
\hline
\end{tabular}

* Angka-angka yang diikuti oleh huruf kecil yang tidak sama pada lajur yang sama adalah berbeda nyata berdasarkan DNMRT pada $\alpha=5 \%$. 
Tanaman tomat yang diintroduksi formula padat $B$. cereus strain TLE1.1 menunjukkan pengaruh terhadap keparahan penyakit yang berbeda nyata (Tabel 3). Perlakuan formula ampas tahu, ampas tahu + tongkol jagung, ampas tebu, ampas tebu + tongkol jagung, ampas tebu +ampas tahu menunjukkan hasil berbeda tidak nyata dengan mancozeb, namun berbeda nyata dengan kontrol negatif. Formula terbaik memperlambat kejadian penyakit busuk pangkal batang pada tomat yaitu formula ampas tahu dan ampas tahu + tongkol jagung yang ditandai tidak adanya penyakit $(0,00)$ dan efektifitas (100\%) (Tabel 2).

Tabel 3. Keparahan penyakit busuk pangkal batang yang diintroduksi formula padat $B$. cereus strain TLE1.1

\begin{tabular}{lcc}
\hline Perlakuan & Keparahan penyakit* & Efektivitas (\%) \\
\hline Ampas tahu & $0,00 \mathrm{a}$ & 100,00 \\
Ampas tahu + tongkol jagung & $0,00 \mathrm{a}$ & 100,00 \\
Ampas tebu & $8,89 \mathrm{ab}$ & 73,32 \\
Ampas tebu + ampas tahu & $8,89 \mathrm{ab}$ & 73,32 \\
Ampas tebu + tongkol jagung & $8,89 \mathrm{ab}$ & 73,32 \\
Mancozeb & $20,00 \mathrm{abc}$ & 39,99 \\
Tongkol jagung & $28,89 \mathrm{bc}$ & 13,32 \\
Kontrol negatif (diinokulasi S. rolfsii) & $33,33 \mathrm{c}$ & 0,00 \\
\hline
\end{tabular}

* Angka-angka yang diikuti oleh huruf kecil yang tidak sama pada lajur yang sama adalah berbeda nyata berdasarkan DNMRT pada $\alpha=5 \%$

Tanaman tomat yang diintroduksi formula padat $B$. cereus strain TLE1.1 menunjukkan pengaruh berbeda nyata pada daya muncul lapang bibit tomat (Tabel 4). Perlakuan tongkol jagung, ampas tebu + ampas tahu, ampas tebu + tongkol jagung, ampas tebu, ampas tahu + tongkol jagung berbeda tidak nyata dengan Mancozeb dan berbeda nyata dengan kontrol positif. Formula terbaik dalam meningkatkan daya muncul lapang adalah formula ampas tahu dengan efektivitas tertinggi $(14,67 \%)$.

Tabel 4. Daya muncul lapang bibit tomat yang diintroduksi formula padat $B$. cereus strain TLE1.1

\begin{tabular}{lcc}
\hline Perlakuan & Daya muncul lapang* & Efektivitas (\%) \\
\hline Kontrol positif (tanpa perlakuan) & 29,50 a & 0,00 \\
Mancozeb & 31,50 ab & 6,77 \\
Tongkol jagung & 32,50 bc & 10,16 \\
Ampas tebu+ampas tahu & 32,22 bc & 10,16 \\
Ampas tebu+tongkol jagung & 32,50 bc & 10,16 \\
Ampas tebu & 32,66 bc & 10,71 \\
Ampas tahu+tongkol jagung & 32,66 bc & 10,71 \\
Ampas tahu & 33,83 def & 14,67 \\
\hline
\end{tabular}

* Angka-angka yang diikuti oleh huruf kecil yang tidak sama pada lajur yang sama adalah berbeda nyata berdasarkan DNMRT pada $\alpha=5 \%$. 
Tanaman tomat yang diintroduksi formula padat $B$. cereus strain TLE1.1 menunjukkan pengaruh berbeda nyata (Tabel 5). Perlakuan ampas tebu, tongkol jagung menunjukkan tidak berbeda nyata dengan kontrol positif. Formula terbaik dalam meningkatkan tinggi bibit adalah formula ampas tahu dengan efektivitas $(38,44 \%)$.

Tabel 5. Tinggi bibit tomat yang diintroduksi formula padat $B$. cereus strain TLE1.1

\begin{tabular}{lcc}
\hline Perlakuan & Tinggi Bibit (cm)* & Efektivitas (\%) \\
\cline { 2 - 3 } Kontrol positif (tanpa perlakuan) & $5,93 \mathrm{a}$ & 0,00 \\
Ampas tebu & $6,30 \mathrm{a}$ & 6,23 \\
Tongkol jagung & $6,85 \mathrm{a}$ & 15,51 \\
Mancozeb & $7,55 \mathrm{bc}$ & 27,31 \\
Ampas tahu + tongkol jagung & $7,68 \mathrm{bc}$ & 29,51 \\
Ampas tebu + tongkol jagung & $7,70 \mathrm{bc}$ & 29,84 \\
Ampas tebu + ampas tahu & $7,90 \mathrm{bc}$ & 33,22 \\
Ampas tahu & $8,21 \mathrm{cde}$ & 38,44 \\
\hline
\end{tabular}

* Angka-angka yang diikuti oleh huruf kecil yang tidak sama pada lajur yang sama adalah berbeda nyata berdasarkan DNMRT pada $\alpha=5 \%$.

Tanaman tomat yang diintroduksi formula padat $B$. cereus strain TLE1.1 menunjukkan pengaruh berbeda nyata pada jumlah daun bibit tomat (Tabel 6). Hanya perlakuan ampas tongkol jagung yang menujukkan hasil berbeda nyata dengan kontrol positif dan Mancozeb. Formula terbaik dalam meningkatkan jumlah daun bibit adalah formula tongkol jagung dengan efektivitas $(28,75 \%)$.

Tabel 6. Jumlah daun bibit tomat yang diintroduksi formula padat $B$. cereus strain TLE1.1

\begin{tabular}{lclc}
\hline \multicolumn{1}{c}{ Perlakuan } & Jumlah daun bibit* & Efektivitas (\%) \\
\hline Kontrol positif (tanpa perlakuan) & 4,66 a & 0,00 \\
Mancozeb & 4,83 ab & 3,64 \\
Ampas tebu & 5,00 abc & 7,29 \\
Ampas tahu & 5,00 abc & 7,29 \\
Ampas tebu + ampas tahu & 5,33 abcd & 14,37 \\
Ampas tebu + tongkol jagung & 5,33 abcd & 14,37 \\
Ampas tahu + tongkol jagung & 5,50 abcde & 18,02 \\
Tongkol jagung & 6,00 defg & 28,75
\end{tabular}

* Angka-angka yang diikuti oleh huruf kecil yang tidak sama pada lajur yang sama adalah berbeda nyata berdasarkan DNMRT pada $\alpha=5 \%$.

Tanaman tomat yang diintroduksi formula padat $B$. cereus strain TLE1.1 menunjukkan pengaruh tidak berbeda nyata terhadap berat basah bibit tanaman tomat (Tabel 7). Semua perlakuan menunjukkan hasil tidak berbeda nyata dengan mancozeb dan kontrol positif. Formula terbaik dalam meningkatkan berat basah bibit adalah formula ampas tebu dengan efektivitas $21,97 \%$. 
Tabel 7. Berat basah bibit tomat yang diintroduksi formula padat B. cereus strain TLE1.1

\begin{tabular}{lcc}
\hline Perlakuan & Berat Basah Bibit* & Efektivitas (\%) \\
\hline Kontrol positif (tanpa perlakuan) & $0,91 \mathrm{a}$ & 0,00 \\
Ampas tebu + tongkol jagung & $0,95 \mathrm{ab}$ & 4,39 \\
Ampas tahu + tongkol jagung & $0,96 \mathrm{ab}$ & 5,49 \\
Mancozeb & $0,96 \mathrm{ab}$ & 5,49 \\
Ampas tahu & $0,98 \mathrm{ab}$ & 7,69 \\
Tongkol jagung & $1,01 \mathrm{ab}$ & 10,98 \\
Ampas tebu + ampas tahu & $1,10 \mathrm{abc}$ & 20,87 \\
Ampas tebu & $1,11 \mathrm{abc}$ & 21,97 \\
\hline
\end{tabular}

*Angka-angka yang diikuti oleh huruf kecil yang tidak sama pada lajur yang sama adalah berbeda nyata berdasarkan DNMRT pada $\alpha=5 \%$

Tanaman tomat yang diintroduksi formula padat $B$. cereus strain TLE1.1 menunjukkan pengaruh tidak berbeda berbeda nyata pada berat kering bibit tomat (Tabel 8). Semua perlakuan menunjukkan hasil tidak berbeda nyata dengan mancozeb dan kontrol positif. Formula terbaik dalam meningkatkan berat kering bibit adalah formula ampas tebu dengan efektivitas (28,57\%).

Tabel 8. Berat kering bibit tomat yang diintroduksi formula padat B. cereus strain TLE1.1

\begin{tabular}{lcc}
\hline Perlakuan & Berat Kering Bibit* & Efektivitas (\%) \\
\hline Kontrol positif (tanpa perlakuan) & $0,07 \mathrm{ab}$ & 0,00 \\
Ampas tebu + tongkol jagung & $0,07 \mathrm{ab}$ & 0,00 \\
Mancozeb & $0,07 \mathrm{ab}$ & 0,00 \\
Ampas tahu + tongkol jagung & $0,08 \mathrm{abc}$ & 14,28 \\
Ampas tebu + ampas tahu & $0,08 \mathrm{abc}$ & 14,28 \\
Ampas tahu & $0,08 \mathrm{abc}$ & 14,28 \\
Tongkol jagung & $0,08 \mathrm{abc}$ & 14,28 \\
Ampas tebu & $0,09 \mathrm{bc}$ & 28,57 \\
\hline
\end{tabular}

* Angka-angka yang diikuti oleh huruf kecil yang tidak sama pada lajur yang sama adalah berbeda nyata berdasarkan DNMRT Test pada $\alpha=5 \%$.

Formula padat $B$. cereus strain TLE1.1 mampu memperlambat masa inkubasi, menekan kejadian dan keparahan penyakit busuk pangkal batang dibandingkan kontrol negatif (diinokulasi S. rolfsii) dan Mancozeb. Formula terbaik dalam mengendalikan $S$. rolfsii yaitu formula ampas tahu dan ampas tahu +tongkol jagung. Hal ini didukung oleh Abidin et al. (2015), yang menyatakan bahwa Bacillus sp. mampu menekan penyakit rebah semai yang disebabkan oleh $S$. rolfsii secara in vivo. Selanjutnya salah satu keberhasilan $B$. cereus strain TLE1.1 yaitu sebagai agen biokontrol Ralstonia solanacearum dan Fusarium oxysporum f. sp solani secara in planta (Yanti et al., 2017).

Semua formula padat $B$. cereus strain TLE1.1 yang dintroduksikan terhadap benih tomat mampu meningkatkan pertumbuhan bibit tomat. Hal ini diduga karena adanya kandungan nutrisi dari bahan pembawa yang mendukung pertumbuhan bibit tomat. Formula dengan bahan pembawa limbah padat tahu mampu meningkatkan pertumbuhan tanaman kedelai dan 
menekan penyakit pustul bakteri (Yanti et al., 2017).

Hampir semua formula padat $B$. cereus strain TLE1.1 dapat meningkatkan pertumbuhan tanaman tomat pada fase vegetatif. Hal ini diduga karena $B$. cereus strain TLE1.1 mampu menghasilkan hormon-hormon pertumbuhan sehingga dapat merangsang pertumbuhan tanaman tomat pada fase vegetatif. Menurut Oktrisna et al. (2017), bakteri endofit mempunyai peranan dalam mengkolonisasi perakaran tanaman dan masuk ke dalam jaringan tanaman kemudian menghasilkan hormon pemacu pertumbuhan tanaman yang dapat merangasng pertumbuhan akar lateral sehingga penyerapan unsur hara lebih optimal. Hal tersebut didukung oleh penelitian Yanti et al. (2017), yang menyatakan bahwa $B$. cereus strain TLE1.1 menghasilkan IAA dengan konsentrasi tertinggi (42,5 ppm). Selanjutnya, Joo et al. (2004), menyatakan bahwa B. cereus mampu meningkatkan pertumbuhan tanaman dengan menghasilkan hormon pertumbuhan seperti giberelin.

\section{SIMPULAN}

Semua formula padat $B$. cereus strain TLE1.1 dapat menekan perkembangan penyakit busuk pangkal batang. Formula terbaik dalam mengendalikan $S$. rolfsii yaitu formula ampas tahu dan ampas tahu+tongkol jagung.

\section{UCAPAN TERIMAKASIH}

Penulis mengucapkan terima kasih yang sebesar-besarnya kepada "Klaster Riset Penerapan Guru Besar Uiversitas Andalas" batch 21 dengan kontrak No. T/2/UN.16.17/PP.Pangan-PTUKRP2GB-
Unand/Ippm/2021 pada 30 Maret 2021 yang telah mendanai penelitian ini.

\section{DAFTAR PUSTAKA}

Abidin, Z., Aini, L. Q., \& Abadi, A. L. (2015). Pengaruh bakteri Bacillus sp. dan Pseudomonas $s p$. terhadap pertumbuhan jamur patogen Sclerotium rolfsii Sacc. penyebab penyakit rebah semai pada tanaman kedelai. Jurnal Hama dan Penyakit Tumbuhan, 3(1), 1-10. http://jurnalhpt.ub.ac.id/index.php/j hpt/article/view/158

Diarta, I. M., Javandira, C., \& Widnyana, I. K. (2016). Antagonistik Bakteri Pseudomonas Spp. Dan Bacillus Spp. Terhadap Jamur Fusarium Oxysporum Penyebab Penyakit Layu Tanaman. Jurnal Bakti Saraswati, 5(1), 70-76. https://media.neliti.com/media/publi cations/74991-ID-none.pdf

Dixit, R., Agrawal, L., Gupta, S., Kumar, M., Yadav, S., Chauhan, P., \& Nautiyal, C. (2016). Southern blight disease of tomato control by 1aminocyclopropane-1-carboxylate (ACC) deaminase producing Paenibacillus lentimorbus B-30488. Plant Signaling \& Behavior, 11, 0. https://doi.org/10.1080/15592324.20 15.1113363

Flori, F., Mukarlina, \& Rahmawati. (2020). Potensi antagonis isolat bakteri bacillus spp. asal rizosfer tanaman lada (Piper nigrum L.) sebagai agen pengendali jamur fusarium sp. JDF. Bioma, 5(1), 111-120. https://doi.org/https://doi.org/10.20 956/bioma.v5i1.9923

Joo, G. J., Kim, Y. M., Lee, I. J., Song, K. S., \& Rhee, I. K. (2004). Growth promotion of red pepper plug seedlings and the production of gibberellins by Bacillus cereus, Bacillus macroides and Bacillus pumilus. Biotechnology 
Letters, 26(6), 487-491. https://doi.org/https://doi.org/10.10 23/B:BILE.0000019555.87121.34

Kator, L., Yula Hosea, Z., \& Daniel Oche, O. (2015). Sclerotium rolfsii; Causative organism of southern blight, stem rot, white mold and sclerotia rot disease. Scholars Research Library Annals of Biological Research, 6(11), 78-89. http://scholarsresearchlibrary.com/ar chive.html

Klement, Z., Rudolph, K., \& Sand, D. . (1990). Methods in Phytophatology. y. Hungary:

Kwon, \& Park, T. (2002). Pictorial atlas of soil and seed fungi morphologies of cultured fungi and key to species (Second edi). CRC Press Boca Raton.

Natalia, A. G., Aeny, T. N., \& Prasetyo, J. (2014). Uji keefektitasan Trichoderma spp. dengan bahan campuran yang berbeda dalam menghambat pertumbuhan Sclerotium rolfsii penyebab penyakit rebah kecambah pada kacang tanah. Jurnal Agrotek Tropika, 2(3), 408-413. https://doi.org/10.23960/jat.v2i3.207 0

Oktania, P., Marwan, H., \& Asniwita, A. (2018). Potensi Bacillus spp. dari rizosfer tanaman kedelai untuk mengendalikan penyakit rebah kecambah (Sclerotium rolfsii Sacc.). Jurnal Agroecotania: Publikasi Nasional Ilmu Budidaya Pertanian, 1(1),19-32.

https://doi.org/10.22437/agroecotani a.v1i1.5333

Oktrisna, D., Puspita, F., \& Zuhry, E. (2017). Uji bakteri Bacillus Sp. endofit diformulasi dengan beberapa limbah terhadap tanaman padi sawah (Oryza Sativa L.). Riau University.

Rivard, C. L., O'connell, S., Peet, M. M., Welker, R. M., \& Louws, F. J. (2012). Grafting tomato to manage bacterial wilt caused by Ralstonia solanacearum in the southeastern United States. Plant disease, 96(7), 973-978.

Saeed, S., Butt, B. Z., Sana, N., \& Javaid, A. (2016). Biological control of Sclerotium rolfsii through the leaf extract of Melia azedarach L. and Syzigium cumini. J. Med. Plant, 4(5), 259-261.

Sahu, P. K., Brahmaprakash, G. P., Gupta, A., Saxena, A. K., Singh, S., \& Singh, U. B. (2019). Antagonistic potential of bacterial endophytes and induction of systemic resistance against collar rot pathogen Sclerotium rolfsii in tomato. Biological Control: Theory and Applications in Pest Management, 137, Not Available. https://doi.org/10.1016/j.biocontrol. 2019.104014

Schaad, N. ., Jones, J. ., \& Chun, W. (2001). Laboratory Guide for Identification of Plant Pathogenic Bacteria (3rd). APS Press.

Sekhar, J. C., Mishra, J. P., Prasad, R., Reddy, V. P., Kumar, S., Thakur, A., \& Pal, J. (2020). Isolation and in vitro evaluation of biocontrol agents, fungicides and essential oils against stem blight of tomato caused by Sclerotium rolfsii (Curzi) CC Tu \& Kimber. J Pharmacogn Phytochem, 9(3),700-705.

https://www.phytojournal.com/archi ves/2020/vol9issue3/PartK/9-3-28-

316.pdf

Taghavi, S., Barac, T., Greenberg, B. Borremans, B., Vangronsveld, J., \& van der Lelie, D. (2005). Horizontal gene transfer to endogenous endophytic bacteria from poplar improves phytoremediation of toluene. Applied and Environmental Microbiology, 71(12), 8500-8505. https://doi.org/10.1128/aem.71.12.8 500-8505.2005 
Wang, S.-S., Liu, J.-M., Sun, J., Sun, Y.-F., Liu, J.-N., Jia, N., Fan, B., \& Dai, X.-F. (2019). Diversity of cultureindependent bacteria and antimicrobial activity of culturable endophytic bacteria isolated from different Dendrobium stems OPEN. Scientific Reports, 9(10389), 1-12. https://doi.org/10.1038/s41598-01946863-9

Watanabe, T. (2002). Pictorial atlas of soil and seed fungi morphologies of cultured fungi and key to species (Second). CRC Press Boca Raton London Newyork.

Wijayanti, E., \& Susila, A. D. (2013).
Pertumbuhan dan produksi dua varietas tomat (Lycopersicon esculentum Mill.). Bul. Agrohorti, 1(1), 104-112.

https://doi.org/https://doi.org/10.29 244/agrob.1.1.104-112

Yanti Yulmira, Warnita, W., Reflin Reflin, \& Busniah Muzir. (2017). Identification and characterizations of potential indigenous endophytic bacteria which had ability to promote growth rate of tomato and biocontrol agents of Ralstonia solanacearum and Fusarium oxysporum fsp. solani. Microbiology Indonesia, 11(4), 117-122. https://doi.org/10.5454/mi.11.4.2 